\title{
Inhalation of Aspergillus fumigatus spores induces airway inflammation in mice in a similar manner as observed in Recurrent Airway Obstruction in horses
}

\author{
Inhalación de esporas de Aspergillus fumigatus induce en ratones una inflamación de las vías \\ aéreas similar a la observada en equinos con Obstrucción Recurrente de las Vías Aéreas
}

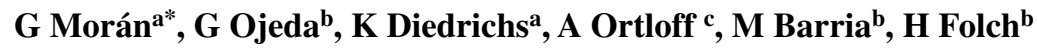

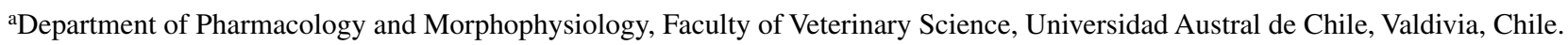 \\ ${ }^{b}$ Department of Immunology, Faculty of Medicine, Universidad Austral de Chile, Valdivia, Chile. \\ ${ }^{\mathrm{c}}$ College of Veterinary Medicine, Universidad Catolica de Temuco, Chile.
}

\begin{abstract}
RESUMEN
El objetivo de este estudio fue determinar si ratones expuestos a esporas de Aspergillus fumigatus desarrollan una inflamación alérgica de las vías respiratorias similar a la observada en equinos con Obstrucción Recurrente de las Vías Aéreas (ORVA). Para esto se utilizaron ratones Rockefeller (RK) de 2, 5, 6 y 8 meses respectivamente, los cuales se mantuvieron por 16 días en jaulas que contenían heno contaminado con A. fumigatus. Posterior a la exposición, los animales fueron sangrados y sacrificados para la obtención de suero sanguíneo, lavado broncoalveolar (LBA) y muestras de tejido pulmonar. Además, se midieron los niveles de anticuerpos específicos para A. fumigatus a través de un ELISA indirecto. Los resultados mostraron que la inhalación de esporas de A. fumigatus en ratones induce una respuesta alérgica inflamatoria en pulmones similar a lo observado en ORVA equino, con un aumento del porcentaje de neutrófilos en el LBA y cambios histológicos pulmonares característicos de una hipersensibilidad bronquial. Asimismo, se observó un aumento de los niveles de inmunoglubulinas IgE, IgG1 e IgG2a específicas para este hongo en fluidos bronquiales. Además, los animales remitieron el estrés respiratorio cuando fueron expuestos en un ambiente de remisión. Se puede concluir que la simple exposición de esporas de $A$. fumugatus produce una condición alérgica similar al ORVA en equinos. Por lo tanto, este modelo experimental puede ser de utilidad para el estudio de los mecanismos inmunológicos, y probar nuevas opciones terapéuticas para esta enfermedad respiratoria de los caballos.
\end{abstract}

Key words: Aspergillus fumigatus, RAO, airway inflammation, mice, horses.

Palabras clave: Aspergillus fumigatus, ORVA, inflamación de las vías aéreas, ratones, equinos.

\section{INTRODUCTION}

Recurrent Airway Obstruction (RAO) in horses, also known as heaves, is a complex, severe and common respiratory disorder that affects stabled horses (Dixon et al 1995, Jackson et al 2000, Robinson 2001). It is caused by an aberrant immune response to inhaled antigens and is characterized by coughing, respiratory distress, reversible airway obstruction and reduced physical performance (Jackson et al 2000, Robinson 2001).

Aspergillus fumigatus is a saprophyte fungus, which survives and grows over a large variety of organic remains and whose most common ecological niche is on the ground. It is one of the most ubiquitous fungi, due to the ease of dispersion of its conidia (Rementeria et al 2005). This fungus is commonly found in the horse environment and is considered one of the inciting agents in equine heaves (McPherson et al 1979, Derksen et al 1988). Studies suggest that RAO-affected horses have higher titers of antibodies to A. fumigatus extracts in bronchoalveolar lavage fluid (BALF) compared to healthy

Accepted: 19.01.2011.

* gmoran@uach.cl control horses (Halliwell et al 1993, Schmallenbach et al 1998, Eder et al 2000). Moran et al (2009) showed that healthy and RAO-affected animals have specific circulating antibodies against the crude mold extract from this fungus. In addition, using an in vitro bioassay, Moran et al (2010) demonstrated that $30 \%$ of thirty RAO-affected horses tested positive for A. fumigatus, which indicates a wide distribution for this allergen.

Airway inflammation is a component of a RAO affected horse's response to aeroallergens and is considered to be one of the primary characteristics of this disease. In general, airway inflammation in RAO-affected horses involves the activation of pathogen specific inflammatory cells, modulation of gene transcription factors and the release of inflammatory mediators (Bureau et al $2000^{\mathrm{a}, \mathrm{b}}$ ). Type I hypersensitivity, which is IgE-mediated (Halliwell et al 1993, Schmallenbach et al 1998, Eder et al 2000, Eder et al 2001, Curik et al 2003, Künzle et al 2007, Tahon et al 2009, Moran et al 2010 a,b), and type III hypersensitivity reactions have been suggested to play a role in airway inflammation in RAO-affected horses (Franchini et al 2000, Lavoie et al 2001).

On the other hand, in humans, A. fumigatus represents a real threat for immunocompromised individuals, such as patients suffering from leukemia, individuals infected with 
HIV, and those who have undergone organ transplants. In normal individuals, cases of allergic disease and mycotoxicosis have also been reported (Rementeria et al 2005). Several experimental mouse models have been proposed for the study of allergic bronchopulmonary aspergillosis (ABPA) in humans. The majority of these models require parenteral immunization, followed by nasal instillation of the antigen. This model results in a Th2-oriented immune response, the production of $A$. fumigatus-specific $\operatorname{IgE}$, and eosinophilic pulmonary inflammation (Kurup et al 2001, Randolph et al 1999, Huang et al 2001).

It is commonly accepted that RAO disease is a bronchial hypersensitivity reaction induced by inhaled molds and organic dust (Derksen et al 1988, McGorum et al 1993). However, although the immunological aspects of RAO have been extensively studied, the precise sequence of events is not fully understood (Leguillette 2003, Wagner 2009). In addition, these investigations have been hampered by problems with the use of antibodies for the detection of equine IgE (Tahon et al 2009) and the lack of suitable immunological tools. A rodent model with controlled environmental conditions would be useful and may provide additional information about RAO in horses. In this study, we show that mice naturally exposed to A. fumigatus develop a disease with characteristics that are similar to RAO in horses. These characteristics include remission of signs after antigen removal, recurrence of disease upon antigen re-exposure, intense neutrophilic infiltration in the airways, and histopathological lung changes.

\section{MATERIAL AND METHODS}

\section{ANIMALS}

For all experiments, we used 2- to 8-month-old, sexand age-matched Rockefeller (RK) mice. The animals were obtained from, and maintained at the Animal Facility of the Universidad Austral de Chile. During exposure to A. fumigatus, the animals were placed in an isolation room with the appropriate ventilation and filtering systems. This study was approved by the Bioethics Committee for the Use of Animals in Biomedical Research of the Universidad Austral de Chile.

\section{ANTIGENIC PREPARATIONS OF A. FUMIGATUS}

The culturing of A. fumigatus was carried out in two steps. The fungus was first cultured in peptone agar for 7 days at $37^{\circ} \mathrm{C}$ and then in malt broth for an additional 7 days. The resulting fungi were used for soluble protein extraction and for the contamination of mouse bedding. For protein extraction, fungi were blended and subsequently sonicated (Ultrasonic Homogenizer, series 4710 Cole Parmer, USA). The resulting suspension was centrifuged at $12,500 \mathrm{x} \mathrm{g}$ for $10 \mathrm{~min}$ and the supernatant, which contained the soluble proteins, was stored at $-20{ }^{\circ} \mathrm{C}$ for later use. To expose mice to A. fumigatus, under conditions that are similar to those confronted by horses affected with this pathogen, good quality hay was sterilized and sprinkled with water containing fungus spores. The contaminated hay was then placed into plastic bags and incubated for 48 hours or more until mold contamination became visible. At this point, the contaminated hay was used as bedding in the mouse cages. During the experiment, animals were maintained under these conditions according to the design of each experiment.

\section{EXPOSURE OF MICE TO A. FUMIGATUS SPORES}

Different groups of 2-, 5-, 6- and 8-month-old mice (eight mice per group) were housed in cages with sterile or A. fumigatus contaminated hay bedding and were kept in an isolation room for 16 days. Each day, after being exposed to the fungus, the animals were carefully observed twice a day for clinical signs of respiratory distress. After 16 days of mold exposure, the mice were bled and sacrificed to obtain bronchoalveolar lavage fluid (BALF) or lung tissues for histological analysis.

In addition, different groups of 2-, 5-, 6- and 8-monthold mice (eight mice per group) were used to evaluate the recurrence of respiratory distress. For this purpose, the animals that were housed in the contaminated environment and demonstrated clear signs of respiratory distress (such as tachypnea and audible sibilance) were placed in a remission environment, allowing us to observe the disappearance of signs associated with respiratory distress.

\section{BRONCHOALVEOLAR LAVAGE}

Different groups of mice were used for bronchoalveolar lavage (BAL) and analysis of lung tissues to prevent any possible alterations in the histological appearance of the lungs that were due to the lavage. The animals were sacrificed using an overdose of a sodium barbital anesthetic (Serve, USA). For BAL, the trachea was surgically exposed and cannulated with an intravenous catheter ( $22 \mathrm{G} \mathrm{x} \mathrm{1/in),}$ and $500 \mu \mathrm{L}$ of saline solution was slowly administrated into the trachea and immediately recovered. The obtained BALF was centrifuged at $690 \mathrm{x}$ g, and the supernatant was stored at $-20{ }^{\circ} \mathrm{C}$ for later use. The supernatant was used for the analysis of antibody titers, and the cell pellet was used for cytological analyses.

\section{ANALYSIS OF ANTIBODY PRODUCTION}

The levels of Aspergillus-specific immunoglobulins present in BALF and serum were determined by ELISA. Briefly, 96-well polystyrene microplates (Sarstedt, USA) were coated with $10 \mu \mathrm{g} / \mathrm{ml}$ of $A$. fumigatus total protein that was dissolved in carbonate buffer ( $\mathrm{pH} 9)$ and incubated overnight. The plates were blocked with a solution of $5 \%$ non-fat milk, followed by the addition of $100 \mu \mathrm{l}$ of 
the appropriate dilution of BALF (1:1) or serum (1:100) into each well. The plates were incubated at $37{ }^{\circ} \mathrm{C}$ for 2 hours, washed three times and incubated with peroxidaseconjugated anti-mouse $\mathrm{IgE}, \mathrm{IgG} 1$ or $\mathrm{IgG} 2 \mathrm{a}$ antibodies (Santa Cruz, Inc, USA) for an additional 2 hours at $37^{\circ} \mathrm{C}$. After incubation, the plates were thoroughly washed and the reaction was revealed with o-phenylenediamine (OPD; Sigma, USA). The colorimetric reaction was evaluated at $450 \mathrm{~nm}$ using a microplate reader (ELx800, Bio-Tek Instruments, USA).

\section{CYTOLOGY OF BALF AND HISTOLOGICAL ANALYSIS}

Cells recovered from BALF were resuspended in $100 \mu \mathrm{L}$ of saline solution. A $10 \mu \mathrm{l}$ drop of this cell suspension was dried on a glass slide and stained with May-GrünwaldGiemsa. For histological sections, control or experimental lung tissues were fixed in $4 \%$ formaldehyde, embedded in Paraplast, cut into 5- $\mu \mathrm{m}$ sections, and stained with hematoxylin-eosin (Ortloff et al 2010)

\section{STATISTICAL ANALYSIS}

The results of the percentage of neutrophils in the BALF and the analysis of the antibody levels were assessed by ANOVA. When significant, the means were compared using a Tukey's Multiple Comparison Test. The results are reported as the mean $\pm \mathrm{SD}$. A value of $\mathrm{P}<0.05$ was considered significant.

\section{RESULTS}

\section{ANALYSIS OF THE CELLULAR COMPOSITION OF THE BALF}

The differential neutrophil counts in the BALF from A. fumigatus-exposed and non-exposed mice, which were different ages, are shown in figure 1 . The cells recovered from the BALF of the exposed mice exhibited a significant increase in the proportion of polymorphonuclear neutrophils. There were significantly greater proportions of neutrophils in 5-, 6- or 8-month-old mice that were exposed to A. fumigatus compared to the non-exposed mice. Neutrophils were present in the BALF from 2-month-old mice that were exposed to A. fumigatus, but there was no statistically significant difference in this group compared to the non-exposed controls.

\section{HISTOPATHOLOGICAL EVALUATION}

Figures 2 and 3 demonstrate the histopathological changes that occurred in the airways of A. fumigatusexposed and non-exposed mice. Clear changes in airway histopathology were only observed in mice that were older than 5 months of age and had been exposed to A. fumigatus for 16 days. No differences were observed between exposed and non-exposed mice that were 2 months

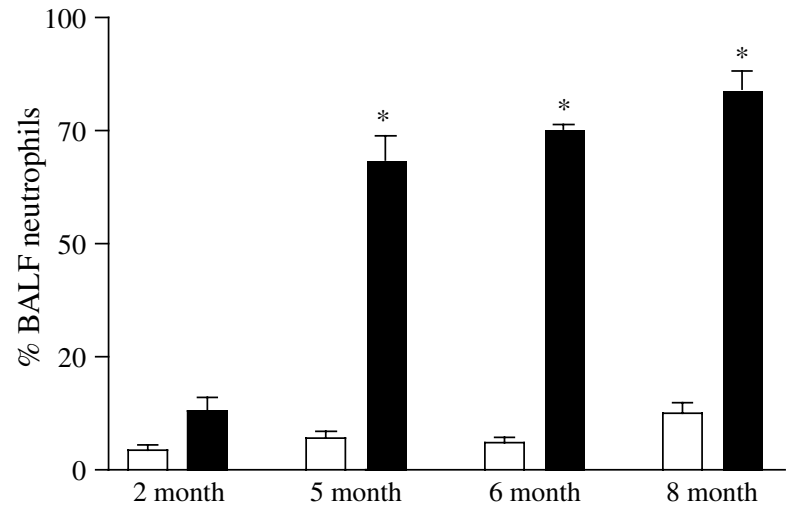

Figure 1. Percentage of neutrophils in bronchoalveolar lavage after being exposed to sterile hay (open bar) or moldy hay (Aspergillus fumigatus) (closed bars) for 16 days ( $n=8$ mice per group). Each bar represents the mean \pm SD of the relative percentage of neutrophils that were obtained from different groups of mice $(* \mathrm{P}<0.05$ comparing sterile hay to moldy hay exposure).

Porcentaje de neutrófilos en el lavado broncoalveolar después de ser expuesto al heno estéril (barra abierta) o heno con esporas (Aspergillus fumigatus) (barras cerradas) durante 16 días ( $\mathrm{n}=8$ ratones por grupo). Cada barra representa la media \pm desviación estándar de la proporción relativa de los neutrófilos que se obtuvieron de los diferentes grupos de ratones $(* \mathrm{P}<0,05$ se compara el heno estéril con la exposición del heno con esporas).

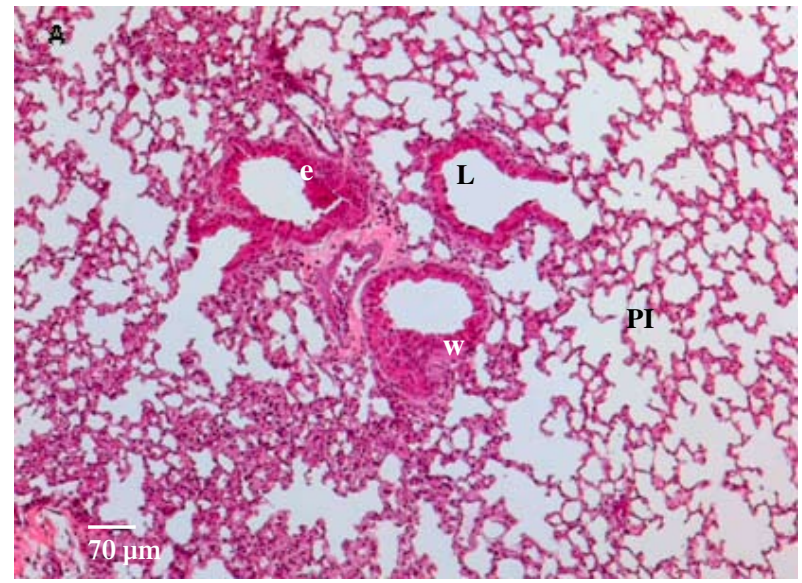

Figure 2. Representative lung histology of one mouse aged (5 month-old) that was exposed to sterile hay for 16 days. The bronchiole contains no inflammatory cell influx within the wall (W), the lumen (L), peribronchial tissue (PI), and the surface epithelium. (e) The lining of the bronchiolar lumen is thin and composed of cuboidal, ciliated and non-ciliated cells. Hematoxylin-eosin stained.

Histología representativa de pulmón de un ratón de 5 meses de edad que se ha expuesto al heno estéril durante 16 días. El bronquiolo no contiene células inflamatorias en la pared (W), lumen (L), tejido peribronquial (PI), y la superficie del epitelio. (e) El revestimiento del lumen bronquial es delgado y está compuesto de células cúbicas, ciliadas y no ciliadas. Tinción Hematoxilina-eosina.

of age. The luminal surface epithelium in the bronchiolar airways of unaffected, non-exposed mice was composed of thin cuboidal epithelial cells. These cells were mostly 


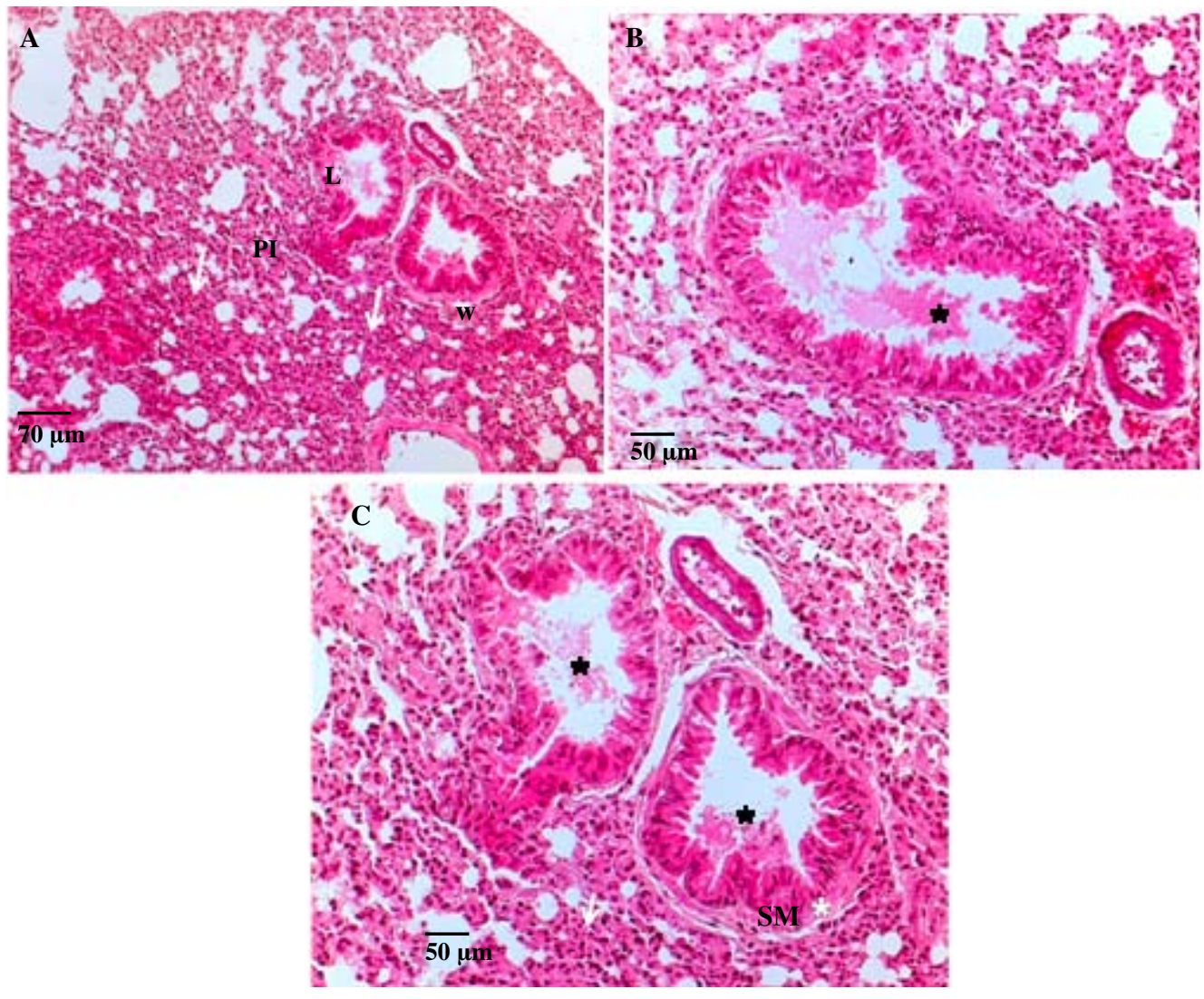

Figure 3. Representative lung histology of mice (5 and 8 month-old) that were exposed to moldy hay (Aspergillus fumigates) for 16 days. (A) Severe atelectasia and peribronchiolar and alveolar infiltration by inflammatory cells (white arrows). (B) Peribronchial infiltration by polymorphonuclear neutrophils and lymphoplasmacytic cells (white arrows). The bronchiolar lumen was stenosed by cells debris (asterisk). (C) Peribronchial infiltration of polymorphonuclear neutrophils and lymphoplasmacytic cells (white arrows). The bronchiolar lumen was stenosed by cells debris (black asterisk) and extensive folding of the airway epithelium was observed. Extensive folding is a sign of smooth muscle (SM) contraction (white asterisk). Hematoxylin-eosin stained.

Histología representativa de pulmón de ratones ( 5 y 8 meses de edad) que fueron expuestas a heno con esporas (Aspergillus fumigatus) durante 16 días. (A) atelectasia grave con infiltración peribronquial y alveolar por células inflamatorias (flechas blancas). (B) Infiltración peribronquial por neutrófilos polimorfonucleares neutrófilos y células linfoplasmacíticas (flechas blancas). El lumen bronquial se observa estenosado por detritus celulares (asterisco). (C) se observa una infiltración peribronquial con polimorfonucleares neutrófilos y células linfoplasmacíticas (flechas blancas). El lumen bronquial se observa estenosado por detritus célulares (asterisco negro) y una exfoliación del epitelio respiratorio. Esta exfoliación es un signo de contracción (SM) músculo liso (asterisco blanco). Tinción Hematoxilina-eosina.

non-ciliated clara cells and ciliated cells that were either with or without a few intervening mucus cells (figure 2). We observed pathological signs in the lungs of animals exposed to A. fumigatus. The bronchiolitis observed in animals exposed to $A$. fumigatus was characterized by significant peribronchiolar and perivascular mononuclear and neutrophilic infiltration, accumulation of intraluminal bronchiolar mucus and serofibrinous exudates. Moreover, there is extensive folding of the airway epithelia, which is a sign of airway smooth muscle contraction and smooth muscle hypertrophy. This inflammatory response was observed predominantly in the peribronchiolar interstitial tissues and often extended into the lamina propria and luminal surface epithelium of the affected airways. We also observed infiltration of inflammatory cells into the alveolar space (figures 3A, 3B and 3C).

\section{ANTIBODY LEVELS IN BALF AND SERUM}

BALF from 5-, 6- and 8-month-old mice, which had been exposed to A. fumigatus, exhibited a significant increase in fungus-specific $\operatorname{IgE}, \operatorname{IgG} 1$ and $\operatorname{IgG} 2 \mathrm{a}$ antibodies when compared to control mice. However, there was no significant difference in the levels of A. fumigatus-specific antibodies in BALF from 2-month-old mice (figure 4). A. fumigatus IgE levels in the serum from the exposed mice in all age groups were significantly greater than the serum levels in the control mice (figure 5A). However, serum IgG1 levels were not significantly different (figure 5B). Serum $\operatorname{IgG} 2$ a levels were only significantly different between the control mice and exposed mice that were older than 6 months of age (figure 5C). 

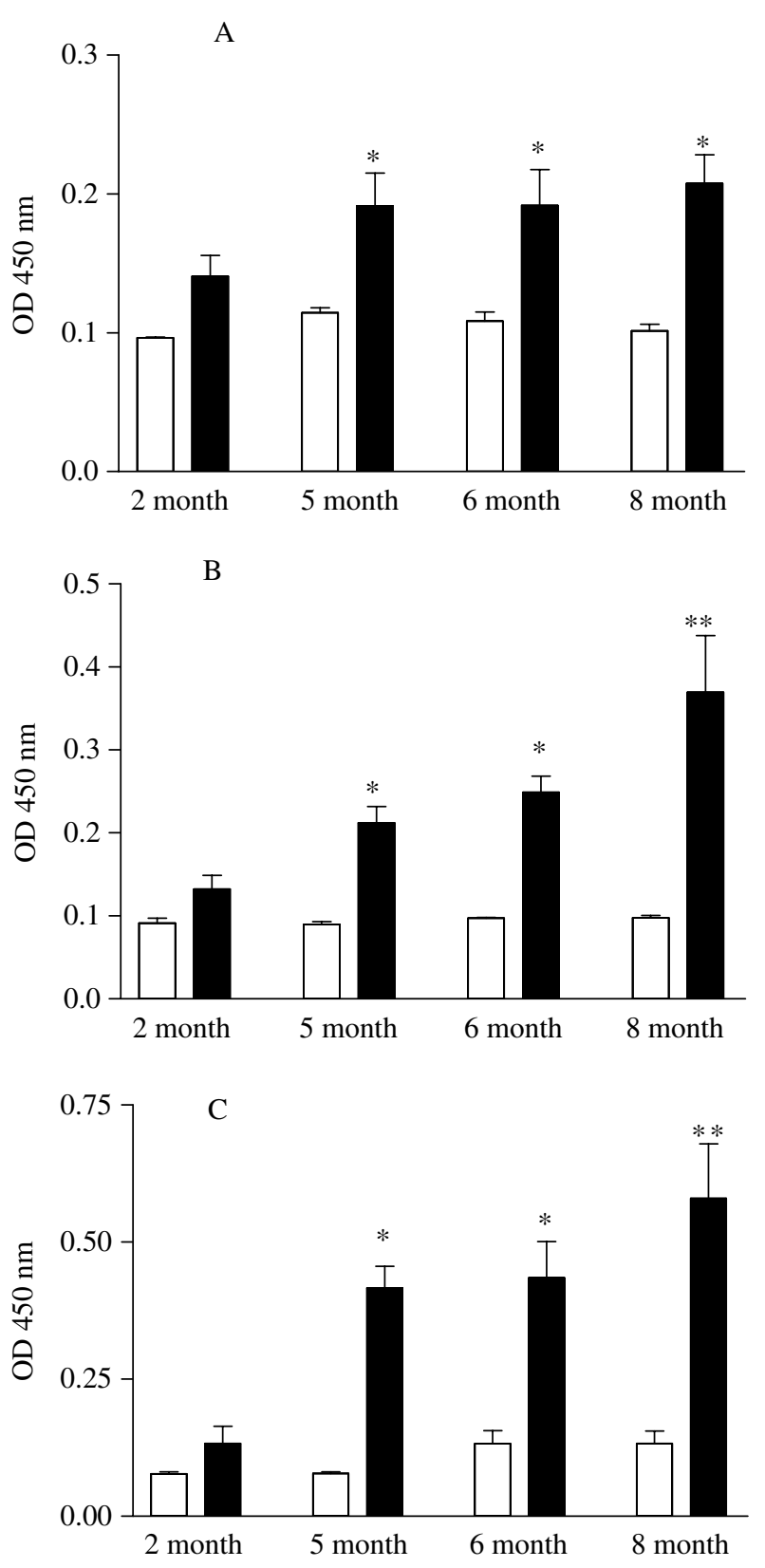

Figure 4. Level of specific $\operatorname{IgE}(\mathrm{A}), \operatorname{IgG} 1$ (B) and $\operatorname{IgG} 2 \mathrm{a}(\mathrm{C})$ against Aspergillus fumigatus in BALF from mice that were exposed to either sterile hay (open bars) or moldy hay (closed bars), 16 days after allergen exposure $(n=8$ mice per group). Each bar represents the mean of the optical density (OD), which was obtained from each of the different groups of mice $(* \mathrm{P}<0,05$; ** $\mathrm{P}<0,01$ comparing sterile hay to moldy hay exposure).

Nivel de IgE (A), IgG1 (B) y IgG2a (C) específicas contra Aspergillus fumigatus en LBA de los ratones que fueron expuestos a heno estéril (barras abiertas) o al heno con esporas (barras cerradas), 16 días después de exposición al alérgeno ( $\mathrm{n}=8$ ratones por grupo). Cada barra representa la media de la densidad óptica (DO) que se obtuvo de cada uno de los diferentes grupos de ratones $(* \mathrm{P}<0.05$, ** $\mathrm{P}<0.01$ se compara la exposición del heno estéril con heno con esporas).
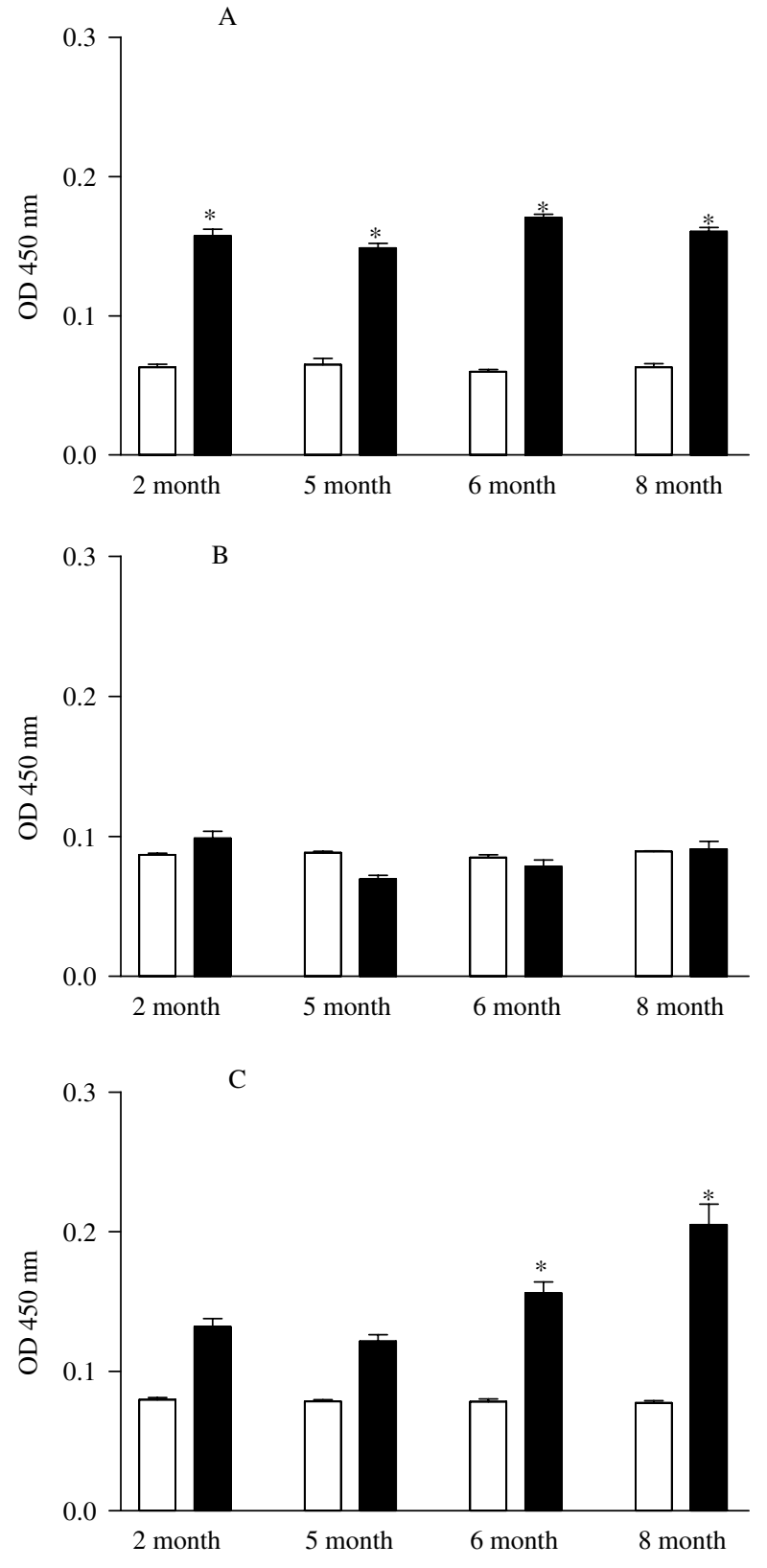

Figure 5. Level of specific $\operatorname{IgE}(\mathrm{A}), \operatorname{IgG} 1$ (B) and $\operatorname{IgG} 2 \mathrm{a}(\mathrm{C})$ against Aspergillus fumigatus in the serum from mice that were exposed to either sterile hay (open bars) or moldy hay (closed bars), 16 days after allergen exposure ( $\mathrm{n}=8$ mice per group). Each bar represents the mean of the optical density (OD), which was obtained from each of the different groups of mice $(* \mathrm{P}<0,05$ comparing sterile hay to moldy hay exposure).

Nivel de IgE (A), IgG1 (B) y IgG2a (C) especificas contra Aspergillus fumigatus en sueros de los ratones que fueron expuestos a heno estéril (barras abiertas) o al heno con esporas (barras cerradas), 16 días después de exposición al alérgeno ( $\mathrm{n}=8$ ratones por grupo). Cada barra representa la media de la densidad óptica (DO) que se obtuvo de cada uno de los diferentes grupos de ratones $(* \mathrm{P}<0.05$, ** $\mathrm{P}<0.01$ se compara la exposición del heno estéril con heno con esporas) 
RECURRENCE OF SIGNS ASSOCIATED WITH RESPIRATORY DISTRESS

Only older mice (5 to 8 months of age) exhibited clear signs of respiratory distress, such as tachypnea and audible sibilance, 16 days after exposure to $A$. fumigatus. The distressed animals displayed a different behavior when compared to control or young mice. The distressed mice also showed a tendency to huddle into groups and remain still. These animals recovered 7 to 8 days after being relocated into a remission environment. After this period, the experimental animals were exposed again, as previously described, to A. fumigatus. However, the mice showed signs of respiratory distress four days after exposure. Same as before, the animals recovered when they were placed in a remission environment. Antigen exposure was repeated one additional time, 2 weeks after the final observation of signs associated with respiratory distress. This time, the onset of respiratory distress was faster (one day after exposure). Once again, the animals recovered when placed in a remission environment.

\section{DISCUSSION}

$\mathrm{RAO}$ in horses is a far more complex condition than allergic diseases, such as insect bite hypersensitivity and atopic asthma in humans (Art et al 2008). Advances have been made in the understanding of the immunological and clinical aspects of RAO in horses. However, it is not yet possible to understand the precise mechanism involved in RAO immunopathology. For this reason, the goal of this study was to generate an experimental mouse model of RAO that closely mimics the condition in horses, which focused on the different stages of exacerbation. Generally, experimental models of various pathophysiological processes are limited because they typically do not recapitulate the disease processes that occur in the original species. However, murine models have contributed to the understanding of the pathogenesis of many diseases and the development of new therapies. Studies on the immunological mechanisms and factors that contribute to the generation of airway inflammation in RAO-affected horses have been hampered due to size of the animal, the relatively long lifespan and the lack of suitable immunological tools. The advantages of mouse models include the availability of large numbers of animals, ease of handling and a large number of immunologic tools. Although there are anatomical differences between the murine lung and the horse lung, our results demonstrate that exposure to A. fumigatus induces airway inflammation in older mice. This inflammatory response is characterized by recurrence upon antigen re-exposure, enhanced polymorphonuclear neutrophil levels in BALF, and histological features that are similar to those described for RAO in horses (Kaup et al 1990a,b, McGorum et al 1993, Robinson 2001, Kleiber et al 2004). This increased immune response is specifically localized to the respiratory tract.

In RAO-affected horses, the infiltration of inflammatory cells in the airway and alveoli is diffuse throughout the lung. Thus, BAL is utilized to diagnose RAO because the inflammatory cells that are recovered should be representative of the overall population of cells in any specific lobular part and is therefore valid for the diagnosis of heaves (McGorum et al 1993 ${ }^{\text {a }}$. Neutrophilic inflammation is the most consistent abnormality that is present in BALF from RAO-affected horses (Derksen et al 1989, McGorum et al 1993 ${ }^{\mathrm{a}}$ ). Neutrophilia in BALF from horses with RAO is positively correlated with airway hyperreactivity (Derksen et al 1985, Dixon et al 1995, Fairbain et al 1993, Robinson 2001). The presence of large numbers of neutrophils in the BALF from animals that were older than five months is an important finding of our study. Our results are coincident with those of a clinical study of RAO-affected horses. Furthermore, older animals that were exposed to A. fumigatus had a higher percentage of neutrophils in the BALF ( $60 \%$ or more), when compared to 2-month-old animals (20\%). In horses, animals that are older than 5 years of age are more frequently affected by RAO compared to younger animals, and the prevalence of RAO increases with age (Leguillette 2003). Cöutil and War (2003) suggest that the incidence of RAO increases until the animals reach 7 to 10 years of age. Once the horses reach this age, the incidence of RAO remains fairly constant. The same phenomenon was observed in our murine model, where airway inflammation and respiratory distress were observed in animals that were older than 5 months of age. However, in our clinical observations, we have found that older horses suffering from RAO sometimes develop clinical exacerbations but do not exhibit a high increase of neutrophils in the BALF. We presume that this finding occurs because these animals are in a more advanced stage of the airway remodeling. Airway smooth muscle remodeling in RAO-affected horses may be involved in airway hyperresponsiveness and chronic lung function impairment through mechanism that are comparable to human asthma (Herzberg et al 2006).

On the other hand, the main histopathological lesion observed in RAO-affected horses is bronchiolitis, which is an accumulation of peribronchiolar lymphocytes that is accompanied by an increase in intraluminal neutrophils (Kaup et al 1990, , Lugo et al 2006, Robinson et al 1996). The mice in our study developed histopathological changes that are coincident with RAO.

A. fumigatus has been shown to be important in the etiology of RAO (Mcpherson et al 1979, Derksen et al 1988, MacGorum et al 1993 ${ }^{\mathrm{a}, \mathrm{b}}$ ). This fungus produces small conidia and spores that can remain suspended in the air for long periods of time. These factors increase the probability of the mold being inhaled by stabled horses (Jackson et al 2000). Moreover, this allergen is present, in large amounts, in the fodder of Chilean horse farms (Araya 
and Zaror 1995). RAO in horses is different from ABPA in humans. In addition to bronchospasms, mononuclear cell infiltration into the lungs, and increased levels of A. fumigatus-specific IgE antibodies, human patients usually exhibit blood and lung eosinophilia (Greenberger et al 2002). The blood and lung eosinophilia is an aspect that is shared with the animal models used to study this human disease (Grüning et al 1997, Kurup et al 1999, Hogoboam et al 1999). Under our experimental conditions, the bronchiolitis observed in the mice was characterized by neutrophil infiltration with a low presence of eosinophils. These findings are similar to the bronchiolitis that occurs in RAO-affected horses.

Compared to healthy animals, horses affected with RAO have significantly higher levels of A. fumigatusspecific IgE and IgG antibodies in their BALF (Halliwell et al 1993, Schmallenbach et al 1998). Our results show that the immune response against $A$. fumigatus allergen, in mice, is characterized by increased levels of antigenspecific IgE, IgG1 and IgG2a antibodies in the BALF. However, the serum levels of these antibody isotypes did not differ between A. fumigatus exposed and non-exposed mice, with the exception of $\operatorname{IgE}$ and $\operatorname{IgG} 2 \mathrm{a}$. IgE and $\operatorname{IgG} 2 \mathrm{a}$ were significantly different in 6- to 8-month-old mice. The same phenomenon occurs in RAO-affected horses (Schmallenbach et al 1998, Eder et al 2000), confirming that local and systemic immune responses are likely regulated independently of one another. Our findings, which show that $\mathrm{IgE}$ and $\mathrm{IgG} 1$ are present in the local airways of mice, are in agreement with previously published results that have shown similar findings in RAO-affected horses (Halliwell et al 1993, Schmallenbach et al 1998, Eder et al 2000). In our study, we show that animals exposed to A. fumigatus showed a significant increase in serum $\operatorname{IgE}$ levels. However, this increase was not observed for IgG1. Although IL-4 stimulates B cell switching to both IgE and $\mathrm{IgG1}$, differences exist in the kinetics of isotype switching in the mouse. The kinetic differences are based on the concentrations of IL-4 that are required to induce isotype switching and the requirements for co-stimulation (Gascan et al 1991, Mandler et al 1993). These observations may partly explain the increased serum IgE levels, compared to the levels of IgG1, in mice exposed to A. fumigatus.

The increased serum and BALF IgE levels suggest that a type I hypersensitivity response may be involved in the pathogenesis of A. fumigatus. Also, the increase in the levels of IgG2a in the BALF from mice that were exposed to allergen is compatible with a Th1 response (Takaoka et al 2001). These findings mimic the conditions typically observed in RAO-affected horses that have elevated levels of $\mathrm{IgGa}$ and IgGb isotypes (Halliwell et al 1993). Moreover, IgG2a can activate the complement cascade, which may partly explain the increase in neutrophils observed in the BALF of mice that were exposed to A. fumigatus. In equines, RAO is characterized by neutrophilic bronchiolitis, which is considered evidence of a type III response that results from antigen-antibody complex formation and the subsequent activation of the complement cascade. These events, in turn, cause a release of the anaphylatoxin peptides, C3a and C5a (Lavoie et al 2001, Franchini et al 2000). A recent study that used IL-4, IFN- $\gamma$ and IL-12 KO mice showed that the respective cytokines play an important role in the inflammatory process. However, each of these cytokines contributes differentially to the inflammatory process and their individual contributions are based on the route of immunization (Fischer et al 2007). In addition, some groups have reported different outcomes of the inflammatory process depending on whether the antigen was delivered orally or nasally. Depending on the route of administration, the resulting inflammation can mimic either eosinophil- or neutrophil- mediated asthma-like diseases (Kurup et al 2001). Here, the challenge of mice with A. fumigatus-contaminated bedding resulted in a significant increase in neutrophils in the BALF and changes in normal lung histology, which is similar to the condition that occurs when horses are exposed to moldy hay.

As mentioned above, IgE-mediated type I reactions and type III reactions have been suggested to be involved in the pathogenesis of heaves (Halliwell et al 1993, Schmallenbach et al 1998, Eder et al 2000, Franchini et al 2000, Eder et al 2001, Lavoie et al 2001, Curik et al 2003, Künzle et al 2007, Tahon et al 2009, Moran et al 2010 a,b). Moreover, recent findings suggest that in addition to the contribution of inflammatory cytokines, such as IL- $1 \beta$, IL-8 and IL-17 (Cordeau et al 2004, Ainsworth et al 2007, Pietra et al 2007, Riihimäki et al 2008), helper T lymphocytes may contribute to the pathogenesis of heaves through their secretion of either Th1 or Th2 cytokines (Giguere et al 2002, Ainsworth et al 2003, Horohov et al 2005). Resident lung cells have also been implicated in the onset of the airway inflammatory response against $A$. fumigatus. Many resident lung cells express lectin and Toll-like receptors that can interact with Aspergillus components. Thus, inhalation of the fungus alone may induce the production of proinflammatory, Th- 1 and Th- 2 cytokines, which may be sufficient to trigger the onset of respiratory airway inflammation (Rementeria et al 2005, Meier et al 2003, Berndt et al 2007). In our study, the progressive nature of the disease that was induced by fungus aspiration indicates that a specific immune response is needed and that this response is probably modulated by cytokines coming from the innate immune system.

In summary, RAO-affected horses spontaneously develop bronchoconstriction and airway inflammation in response to specific airborne irritant and allergen exposure (Robinson 2001). Clinical manifestation of the disease can be tempered by altering environmental conditions to minimize exposure to the causative agents. Therefore, research using this mouse model for the study of equine RAO can offer the opportunity to approximate the immunologic response to airborne irritants and allergens as well as to evaluate pharmacological therapies. We conclude 
that simple exposure of mice to moldy hay induces a spontaneous condition that is similar to RAO in horses, including the recurrent airway inflammation and similar histopathological changes. In due time, this procedure may constitute an experimental model for RAO because the allergic inflammatory reaction we observed here is a very complex phenomenon that accurately mimics RAO in horses. Further studies are warranted to fully understand the pathogenic mechanisms of RAO which, in turn, can lead to new treatment approaches.

\section{SUMMARY}

The aim of this study was to determine if mice exposed to Aspergillus (A.) fumigatus spores develop airway inflammation in a similar manner to Recurrent Airway Obstruction (RAO) in horses. Different groups of 2-, 5-, 6- and 8-month-old Rockefeller (RK) mice were used throughout the experiment. The mice were maintained in the animal house for 16 days and kept in cages containing hay contaminated with A. fumigatus. After 16 days of mold exposure, the mice were bled and sacrificed to obtain bronchoalveolar lavage fluid (BALF) or lung tissues for histological analysis. In addition, we measured the levels of A. fumigatus-specific antibodies by ELISA. The results demonstrated that inhalation of A. fumigatus spores in mice induced an inflammatory response in the lungs that was characterized by peribronchiolar and perivascular mononuclear infiltration and bronchiolar luminal exudates. Moreover, there was extensive folding of the airway epithelia, which is a sign of airway smooth muscle contraction and smooth muscle hypertrophy. In addition, we observed a high number of neutrophils and an increase in IgE, IgG1 and IgG2a antibodies in the BALF from mice that were older than 5 months and were exposed to $A$. fumigatus. These animals recovered from their respiratory distress when they were placed in a remission environment. We conclude that simple exposure of mice to moldy hay induces a condition that is similar to RAO in horses. Therefore, using this mouse model for the study of equine RAO offers the opportunity to approximate the immunologic response to airborne irritants and allergens as well as to evaluate pharmacological therapies.

\section{ACKNOWLEDGEMENTS}

This study was supported by a DID-UACH S-2009-22 grant and BMRC, Chile.

\section{REFERENCES}

Ainsworth DM, B Wagner, HN Erb, JC Young, DE Retallick. 2007. Effects of in vitro exposure to hay dust on expression of interleukin-17, -23 , -8 , and -1 beta and chemokine (C-X-C motif) ligand 2 by pulmonary mononuclear cells isolated from horses chronically affected with recurrent airway disease. Am J Vet Res 68, 1361-1369.

Ainsworth DM, G Grünig, MB Matychak, J Young, B Wagner, HN Erb, DF Antczak. 2003. Recurrent airway obstruction (RAO) in horses is characterized by IFN-g and IL-8 production in bronchoalveolar lavage cells. Vet Immunol Immunopathol 96, 83-91.

Art T, F Bureau, NE Robinson. 2008. Huntig for a key to the enigma of heaves in the blax box of the white cells. Vet $J 177,307-308$

Berndt A, FJ Derksen, PJ Venta, S Ewart, V Yuzbasiyan-Gurkan, NE Robinson. 2007. Elevated amount of Toll-like receptor $4 \mathrm{mRNA}$ in bronchial epithelial cells is associated with airway inflammation in horses with recurrent airway obstruction. Am J Physiol 292, L936-L943.

Bureau F, G Bonizzi, N Kirschvink, S Delhalle, D Desmecht, MP Merville, V Bours, P Lekeux. 2000a . Correlation between nuclear factor- $\mathrm{\kappa B}$ activity in bronchial brushing samples and lung dysfunction in an animal model of asthma. AM J Respir Crit Care Med 161, 1314-1321

Bureau F, S Delhalle, G Bonizzi, L Fievez, S Dogne, N Kirschvink, A Vanderplasschen, MP Merville, V Bours, P Lekeux. 2000b. Mechanisms of persistent NF- $\kappa B$ activity in the bronchi of an animal model of asthma. J Immunol 165, 5822-5830.

Cordeau ME, P Joubert, O Dewachi, Q Hamid, JP Lavoie. 2004. IL-4, IL-5 and IFN-g mRNA expression in pulmonary lymphocytes in equine heaves. Vet Immunol Immunopathol 97, 87-96.

Couëtil LL, MP Ward. 2003. Analysis of risk factors for recurrent airway obstruction in North American horses: 1,444 cases (1990-1999). $J$ Am Vet Med Assoc 223, 1645-1650.

Curik I, D Fraser, C Eder, R Achmann, J Swinburne, M Binns, R Crameri, G Brem, J So lkner, E Marti. 2003. Association between MHC gene region and variation of serum $\operatorname{IgE}$ levels against specific mould allergens in the horse. Genet Select Evol 35, 117-190.

Derksen FJ, NE Robinson, JS Scott, JA Stick. 1988. Aerosolized Micropolyspora faeni antigen as a cause of pulmonary dysfunction in ponies with recurrent airway obstruction (heaves). Am J Vet Res 49, 933-938.

Dixon PM, DI Railton, BC McGorum. 1995. Equine pulmonary disease: a case control study of 300 referred cases. Part 3: Ancillary diagnostic findings. Equine Vet $J$ 27, 428-435.

Eder C, R Crameri, C Mayer, R Eicher, R Straub, H Gerber, S Lazary, E Marti. 2000. Allergen-specific IgE levels against crude mould and storage mite extracts and recombinant mould allergens in sera from horses affected with chronic bronchitis. Vet Immunol Immunopathol 73, 241-253.

Eder C, I Curik, G Brem, R Crameri, I Bodo, F Habe, S Lazary, J So lkner, E Marti. 2001. Influence of environmental and genetic factors on allergen-specific immunoglobulin E levels in sera from Lipizzan horses. Equine Vet J 33, 714-720.

Fairbairn SM, CP Page, P Lees, FM Cunningham. 1993. Early neutrophil but not eosinophil or platelet recruitment to the lungs of allergic horses following antigen exposure. Clin Exp Allergy 23, 821-828.

Fischer R, D Tomé, JR McGhee, PN Boyaka. 2007. Th1 and Th2 cells are required for both eosinophil- and neutrophil-associated airway inflammatory responses in mice. Biochem Biophys Res Commun $25,44-49$.

Franchini M, U Gill, R Von Fellenberg, VV Bracher. 2000. Interleukin-8 concentration and neutrophil chemotactic activity in bronchoalveolar lavage fluid of horses with chronic obstructive pulmonary disease following exposure to hay. Am J Vet Res 11, 1369-1374.

Gascan H, JF Gauchat, G Aversa, P Van Vlasselaer, JE de Vries. 1991. Anti-CD40 monoclonal antibodies or CD4+ T cell clones and IL-4 induce IgG4 and IgE switching in purified human B cells via different signaling pathways. J Immunol 147, 8-13.

Giguere S, L Viel, E Lee, RJ MacKay, J Hernandez, M Franchini. 2002. Cytokine induction in pulmonary airways of horses with heaves and effect of therapy with inhaled fluticasone propionate. Vet Immunol Immunopathol 85, 147-158.

Greenberger PA. 2002. Allergic bronchopulmonary aspergillosis, allergic fungal sinusitis, and hypersensitivity pneumonitis. Clin Allergy Immunol 16, 449-468.

Grünig G, DB Corry, MW Leach, BW Seymour, VP Kurup, DM Rennick. 1997. Interleukin-10 is a natural suppressor of cytokine production and inflammation in a murine model of allergic bronchopulmonary aspergillosis. J Exp Med 185, 1089-1099.

Halliwell RE, BC McGorum, P Irving, PM Dixon. 1993. Local an systemic antibody production in horses affected with chronic obstructive pulmonary disease. Vet Immunol Immunopathol 38, 201-205.

Herszberg B, D Ramos-Barbon, M Tamaoka, JG Martin, JP Lavoie. 2006 . Heaves, an asthma-like equine disease, involves airway smooth muscle remodeling. J Allergy Clin Immunol 118, 382-388.

Hogaboam CM, CS Gallinat, DD Taub, RM Strieter, SL Kunkel, NW Lukacs. 1999. Immunomodulatory role of C10 chemokine 
in a murine model of allergic bronchopulmonary aspergillosis. J Immunol 162, 6071-6079.

Horohov DW, RE Beadle, S Mouch, SS Pourciau. 2005. Temporal regulation of cytokine mRNA expression in equine recurrent airway obstruction. Vet Immunol Immunopathol 108, 237-245.

Huang TJ, PA MacAry, P Eynott, A Moussavi, KC Daniel, PW Askenase, DM Kemeny, KF Cheng. 2001. Allergen-specific Th1 cells counteract efferent Th2 cell-dependent bronchial hyperresponsiveness and eosinophilic inflammation partly via IFN-gamma. J Immunol 166, 207-217.

Jackson CA, C Berney, AM Jefcoat, NE Robinson. 2000. Environment and prednisone interactions in the treatment of recurrent airway obstruction (heaves). Equine Vet J 32, 432-438.

Kaup FJ, W Drommer, E Deegen. 1990ª . Ultrastructural findings in horses with chronic obstructive pulmonary disease (COPD). I: Alterations of the larger conducting airways. Equine Vet J 22, 343-348.

Kaup FJ, W Drommer, S Damsch, E Deegen. 1990 ${ }^{\text {b }}$. Ultrastructural findings in horses with chronic obstructive pulmonary disease (COPD) II: Pathomorphological changes of the terminal airways and the alveolar region. Equine Vet $J$ 22, 349-355.

Kleiber C, BC McGorum, DW Horohov, RS Pirie, A Zurbriggen, R Straub. 2004. Cytokine profiles of peripheral blood and airway CD4 and CD8 T lymphocytes in horses with recurrent airway obstruction. Vet Immunol Immunopathol 104, 91-97.

Künzle F, V Gerber, A van der Haegen, B Wampfler, R Straub, E Marti. 2007. IgE-bearing cells in bronchoalveolar lavage fluid and allergenspecific IgE levels in sera from RAO-affected horses. $J$ Vet Med A Physiol Pathol Clin Med 54, 40-47.

Kurup VP, JQ Xia, R Crameri, DA Rickaby, HY Choi, S Flückiger, K Blaser, CA Dawson, KJ Kelly. 2001. Purified recombinant A. fumigatus allergens induce different responses in mice. Clinical Immunology 98, 327-336.

Kurup VP, JQ Xia, DA Rickaby, CA Dawson, H Choi, JN Fink. 1999. Aspergillus fumigatus antigen exposure results in pulmonary airway resistance in wild-type but not in IL-4 knockout mice. Clin Immunol 93, 404-410.

Lavoie JP, K Maghni, M Desnoyers, R Taha, JG Martin, QA Hamid 2001. Neutrophilic airway inflammation in horses with heaves is characterized by a Th2-type cytokine profile. Am J Respir Crit Care Med 164, 1410-1413.

Leguillette R. 2003. Recurrent airway obstruction-heaves. Vet Clin Equine Prac 19, 63-68.

Lugo J, JR Harkema, H deFeijter-Rupp, L Bartner, D Boruta, NE Robinson. 2006. Airway inflammation is associated with mucous cell metaplasia and increased intraepithelial stored mucosubstances in horses. Vet $J 172$, 293-301.

Mandler R, FD Finkelman, AD Levine, CM Snapper. 1993. IL-4 induction of $\mathrm{IgE}$ class switching by lipopolysaccharide-activated murine B cells occurs predominantly through sequential switching. J Immunol 150, 407-418.

Meier A, CJ Kirschning, T Nikolaus. 2003. Toll-like receptors (TLR) 2 and TLR 4 are essential for Aspergillus-induced activation of murine macrophages. Cell Microbiol 5, 561-570.

McGorum BC, PM Dixon, RE Halliwell. 1993 ${ }^{\text {a }}$ Evaluation of intradermal mould antigen in the diagnosis of equine chronic obstructive pulmonary disease. Equine Vet J 25, 273-275.
McGorum BC, PM Dixon, REW Halliwell. 1993 . Responses of horses affected with chronic obstructive pulmonary disease to inhalation challenge with mould antigens. Equine Vet J 25, 261-267.

McPherson EA, GH Lawson, JR Murphy, JM Nicholson, RG Breeze, HM Pirie. 1979. Chronic obstructive pulmonary disease (COPD) in horses: aetiological studies: responses to intradermal and inhalation antigenic challenge. Equine Vet $J$ 11, 159-166.

Morán G, O Araya, A Ortloff, H Folch. 2009. Cytologic broncheoalveolar lavage findigs and humoral immune response against Aspergillus fumigatus in Chilote horses with Recurrent Airway Obstructions "Heaves". Arch Med Vet 41, 83-88.

Morán G, R Burgos, O Araya, H Folch. 2010a. In vitro bioassay to detect reaginic antibodies from the serum of horses affected with recurrent airway obstruction. Vet Res Commun 34, 91-99.

Morán G, H Folch, R Burgos, O Araya, M Barria. 2010 . Detection of reaginic antibodies against Faenia rectivirgula from the serum of horses affected with Recurrent Airway Obstruction by an in vitro bioassay. Vet Res Commun 34, 719-726.

Ortloff A, G Morán, A Olavarría, H Folch. 2010. Membranoproliferative glomerulonephritis possibly associated with over-vaccination in a cocker spaniel dog. J Small Anim Pract. In press.

Pietra M, A Peli, A Bonato, A Ducci, S Cinotti. 2007. Equine bronchoalveolar lavage cytokines in the development of recurrent airway obstruction. Vet Res Commun 3, 313-316

Randolph DA, R Stephens, CJ Carruthers, DD Chaplin. 1999. Cooperation between Th1 and Th2 cells in a murine model of eosinophilic airway inflammation. J Clin Invest 104, 1021-1029.

Rementeria A, N Lopez-Molina, A Ludwig, AB Vivanco, J Bikandi, J Ponton, J Garaizar 2005. Genes and molecules envolved in Aspergillus fumigatus virulence. Rev Ibero Micol 22, 1-23.

Riihimäki M, A Raine, T Art, P Lekeux, L Couëtil, J Pringle. 2008. Partial divergence of cytokine mRNA expression bronchial tissues compared to broncheoalveolar lavage cells in horses with recurrent airway obstruction. Vet Immunol Immunopathol 122, 256-64.

Robinson NE. 2001. International Workshop on Equine Chronic Airway Disease Michigan State University. Equine Vet J 33, 5-19.

Robinson NE, FJ Derksen, M Olszewski, VA Buechner-Maxwell. 1996. The pathogenesis of chronic obstructive pulmonary disease of horses. Br Vet J 152, 283-306.

Schmallenbach KH, I Rahman, HH Sasse, PM Dixon, RE Halliwell, BC McGorum, HR Miller. 1998. Studies on pulmonary and systemic Aspergillus Fumigatus-specific IgE and IgG antibodies in horses affected with chronic obstructive pulmonary disease (COPD). Vet Immunol Immunopathol 66, 245-256.

Tahon L, S Baselgia, V Gerber, MG Doherr, R Straub, NE Robinson, E Marti. 2009. In vitro allergy test compared to intradermal testing in horses with recurrent airway obstruction. Vet Immunol Immunopathol 127, 85-93

Takaoka A, Y Tanaka, T Tsuji, T Jinushi, A Hoshino, Y Asakura, Y Mita, K Watanabe, S Nakaike, Y Togashi, T Koda, K Matsushima, T Nishimura. 2001. A critical role for mouse CXC chemokine(s) in pulmonary neutrophilia during Th type 1-dependent airway inflammation. J Immunol 167, 2349-2353.

Wagner B. 2009. IgE in horses: Occurrence in health and disease. Vet Immunol Immunopathol 132, 21-30. 